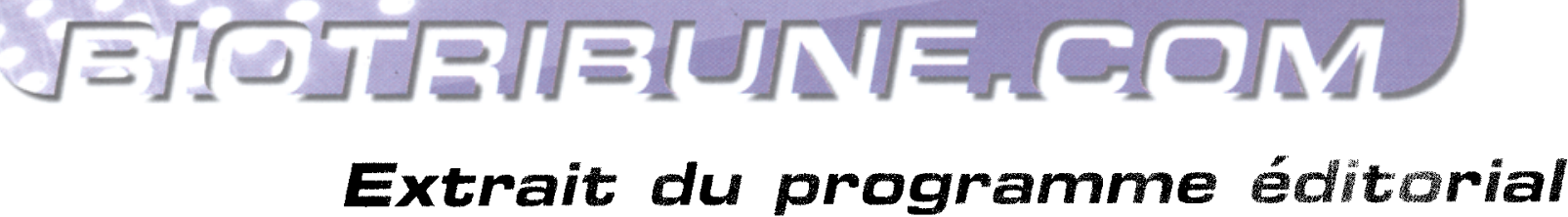

\section{Revue des connaissances}

\section{Virologie}

Dossiers à paraître :

Apport de la biologie moléculaire dans le diagnostic et le suivi de l'hépatite $B$

Par F. Denis, F. Zoulim, F. Dubois

Génotypage du VIH

Par H. Fleury

La non progression des patients $\mathrm{VIH}+$

Par L. Morand Joubert

\section{Biologie moléculaire}

Dossier Paru :

"Spécial PCR" (principe de la PCR et de ses différentes déclinaisons)

Par J. Lamoril et M. Bogard

\section{Compte-rendu de congrès}

Dossier Paru:

Diagnostic des surcharges en fer d'origine moléculaire

Par M. Coudé et A.-M. Jouanolle

Et d'autres Diaporamas des Ateliers du colloque 2001 des Hôpitaux généraux

\section{Hémostase}

Dossier à paraître :

Plaquettes : présent et avenir

Par T. Lecompte et F. Bourre

\section{Espace thématique Thyroïde}

Cas cliniques \& forum d'experts

Consultez le programme en page 15

\section{Espace thématique Biologie délocalisée}

Base documentaire : diaporamas, articles... Table ronde virtuelle : expériences et réflexions sur les enjeux de la biologie délocalisée

\section{Environnement du laboratoire}

\section{Informatique}

A paraître :

La prescription connectée : Table ronde
Publier sur BioTribune : Notes aux auteurs

Vous pouvez soumettre vos articles originaux, vos cas cliniques pour discussion en ligne, au comité éditorial de BioTribune dont la liste des membres est publiée à l'adresse : www.biotribune.com/comite_editorial/

Vos travaux, après acceptation et relecture, pourront ainsi être publiés sur le site BioTribune.com et/ou sur BioTribune Magazine*.

Les modalités de mise en forme et de publication ainsi que les recommandations aux auteurs sont précisées à l'adresse : www.biotribune.com/recommandations_auteurs/

Toute correspondance doit être adressée par e-mail à redaction@biotribune.com

Ou par courrier à l'adresse :

\section{BioTribune \\ Direction de la Rédaction}

15, Rue Réaumur, 75003 PARIS

* Selon le suffrage du sondage en ligne

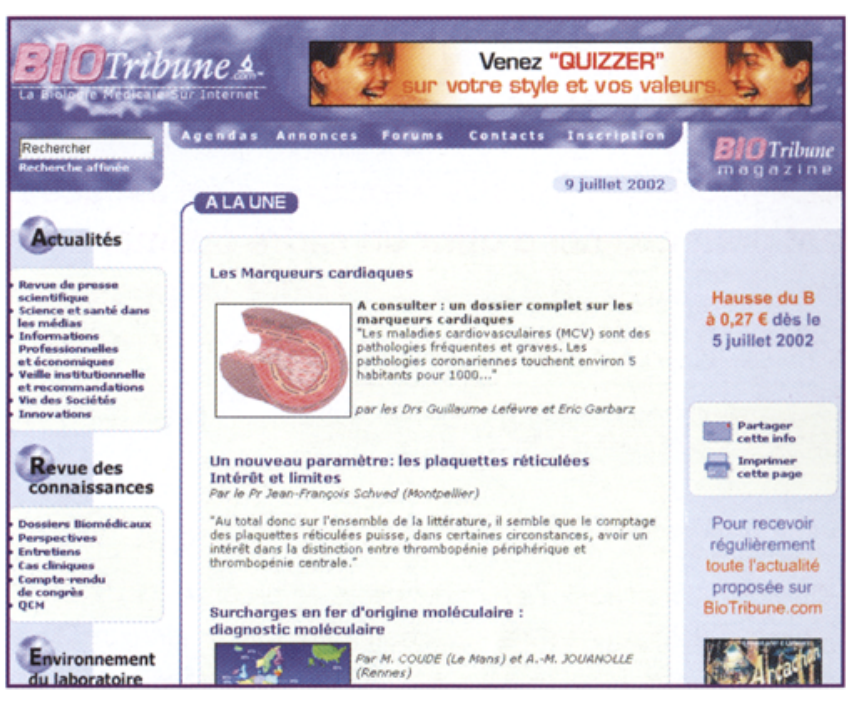

$>$ Pour être informé des nouveautés mises en ligne sur BioTribune.com (actualités, dossiers, cas cliniques forums...) : inscrivez-vous et abonnez-vous à notre lettre d'information sur BioTribune.com. Rejoignez notre espace Professionnel.

> En vous connectant sur BioTribune.com, participez à l'élaboration du programme éditorial de BioTribune.com et de BioTribune magazine. 